Research Article

\title{
Development of Non-Invasive Blood Glucose Level Monitoring System using Phone as a Patient Data Storage
}

\author{
Riska Ekawita ${ }^{1, a, *}$, Ahmad Azmi Nasution ${ }^{2, b}$, Elfi Yuliza ${ }^{1, c}$, Nursakinah Suardi ${ }^{3, d}$ \\ and Suwarsono ${ }^{1, \mathrm{e}}$ \\ ${ }^{1}$ Department of Physics, Faculty of Mathematics and Natural Sciences, University of Bengkulu \\ JalanWR. Supratman, KandangLimun, Bengkulu 38371, Indonesia \\ ${ }^{2}$ Anatomy Department, Faculty of Medicine and Health Sciences, University of Bengkulu \\ JalanWR. Supratman, KandangLimun, Bengkulu 38371, Indonesia \\ ${ }^{3}$ School of Physics, University Sains Malaysia \\ 11800 USM Gelugor, Penang, Malaysia
}

e-mail: 마 rekawita@unib.ac.id, ${ }^{b}$ a.azmi85@gmail.com, ${ }^{c}$ eyuliza@unib.ac.id, ${ }^{d}$ nsakinahsuardi@usm.my, and suwarsono@unib.ac.id

* Corresponding Author

\begin{abstract}
Glucose levels that accumulate in the blood can cause other organ disorders and even cause death. To prevent such occurrence, continuous and regular glucose measuring and monitoring is required for diabetes mellitus (DM) patients. Glucose measurement for DM patients are generally performed several times a day, so be required easy, harmless method of measuring the DM patients, and monitoring data are well recorded. Thus in this research, an android non-invasive glucose level system with wireless communication and automatic data storage on the phone's memory was developed. The study was begun with the built of electronic and software systems as the central part of the measuring system. The electronic section consists of laser and light sensors that respond to a change in blood glucose (BG) levels, the microcontroller that controlled all of the measuring processes, and Bluetooth modules as transceiver on data communication of the android. The software section is built using an App Inventor developed by the Massachusetts Institute of Technology (MIT) to display and store data measurement on the mobile phone. The calibration process of light sensors is done with the standard tool and at last, the wireless communication systems testing and BG levels measurement. The result shows that $94 \mathrm{mg} / \mathrm{dl}$ of BG levels by standard tools equals 2.86 volts of voltage measured by the design system. The higher the BG level, the lower the voltage be. Increase the BG level causes the resistance between the transmitter and the receiver to raise and the voltage becomes low.
\end{abstract}

Keywords: glucose; non-invasive; phone; sensor; microcontroller 


\title{
Pengembangan Sistem Pemantauan Kadar Glukosa Darah Non Invasif Menggunakan Telepon Genggam sebagai Penyimpan Data Pasien
}

\begin{abstract}
Abstrak
Kadar glukosa yang menumpuk pada darah dapat menyebabkan gangguan pada organ tubuh manusia dan bahkan dapat menimbulkan kematian. Untuk mencegah terjadinya hal tersebut, maka diperlukan pengukuran dan pemantauan glukosa secara terus menerus dan teratur bagi pasien diabetes melitus (DM). Pengukuran glukosa untuk pasien DM umumnya dilakukan beberapa kali dalam sehari, sehingga diperlukan metode pengukuran pasien DM yang mudah dan tidak berbahaya, serta data pemantauan yang tercatat dengan baik. Maka pada penelitian ini dikembangkan sistem kadar glukosa noninvasive berbasis android dengan komunikasi nirkabel dan penyimpanan data otomatis pada memori telepon. Penelitian diawali dengan dibangunnya perangkat keras (sistem elektronik) dan perangkat lunak sebagai bagian sentral dari sistem pengukuran. Bagian elektronik terdiri dari laser dan sensor cahaya yang merespon perubahan kadar glukosa darah $(B G)$, mikrokontroler yang mengontrol semua proses pengukuran, dan modul Bluetooth sebagai transceiver pada komunikasi data dengan android. Bagian perangkat lunak dibuat menggunakan App Inventor yang dikembangkan oleh Massachusetts Institute of Technology (MIT) untuk menampilkan pengukuran data di telepon. Proses kalibrasi sensor cahaya dilakukan dengan alat standar dan terakhir, pengujian sistem komunikasi nirkabel dan pengukuran level BG. Hasil penelitian menunjukkan bahwa kadar BG $94 \mathrm{mg} / \mathrm{dl}$ oleh alat standar sama dengan tegangan 2,86 volt yang diukur dengan sistem perancangan. Semakin tinggi level $B G$ membuat tegangan semakin rendah. Peningkatan level $B G$ menyebabkan resistansi antara pemancar dan penerima naik dan tegangan menjadi rendah.
\end{abstract}

Kata Kunci: glukosa; non-invasive; telepon; sensor; mikrokontroler

PACS: 07.50.--e; 07.50.Ek; 07.57.-c; 28.41.Rc; 43.20.Ye

(C) 2020 Jurnal Penelitian Fisika dan Aplikasinya (JPFA). This work is licensed under CC BY-NC 4.0

Article History: Received: August 18, 2020

Accepted: December 22, 2020
Aproved with minor revision: December 3, 2020

Published: December 31, 2020

Howtocite: Ekawita R, et al. Development of Non-Invasive Blood Glucose Level Monitoring System using Phone as a Patient Data Storage. Jurnal Penelitian Fisika dan Aplikasinya (JPFA). 2020; 10(2): 103-113. DOI: https://doi.org/10.26740/jpfa.v10n2.p103-113.

\section{INTRODUCTION}

Diabetes mellitus (DM) is a chronic disease that is related to the abnormal range level of glucose in the blood [1,2]. The level of glucose that accumulates in the blood can disrupt other body organs, causes complications of other diseases, and the worst leads to death [1,3-7]. Glucose can be converted into energy by the insulin produced by the pancreas. Unfortunately, the pancreas of DM patients cannot provide insulin in normal quantity $[8,9]$. This problem makes blood increases significant and homeostasis disturbance, thus it is necessary to monitor glucose levels of the DM patients regularly, continuously and user friendly $[4,5]$.

There are two types of methods in measuring blood glucose (BG) levels, namely invasive and non-invasive methods. The invasive method is done by making a small puncture on the patient and taking a sample of blood $[8,10]$. DM patients sometimes have to prick several times a day, so this method may be uncomfortable, takes a particular time 
to collect blood, and increases the infection risk for patients $[6,11,12]$. Meanwhile, noninvasive methods are carried out without hurting DM patients, so it is more convenient even if measurements are done repeatedly. Both of the methods have been developed to get a simple and an accurate measurement result. The sensor for BG sensing has been varied [5,13-14], even testing and evaluation were also carried out not only to human but also to animals [1,11,15-17].

Non-invasive method is a promising method and preferred by DM patients $[7,18]$. Researchers tried to minimize the invasive method to avoid potential infection in the patient $[10,11]$. Patient's sweat, tears, salivary and breath are used as objects to see the glucose level in the DM patient $[7,19,20]$. Glucose concentrations in blood remain the key parameter for DM patients [7]. So that, detection BG levels through non-invasive method via skin surface needs to be further developed and much effort focusing on it need to be taken [18].

Non-invasive continuous BG monitoring is also garner concern for diabetes management. Self-monitoring is useful to patients in evaluating their body to medication [19]. Self BG monitoring can be done by utilizing the development of electronic information and communication technology, because the monitoring process has become the DM patients' daily life $[11,19,21]$. The display of medical data [3], the storage, analysis and management of medical data monitoring [15,22-24] have become part of studies in self BG monitoring. The wireless communication technology is also carried out in terms of measurement and monitoring of the BG levels [25]. Rodin [5] and Liang [13] has conducted a study of glucose measurement in a non-invasive method using
Bluetooth technology in terms of data transmission, however the data recording is still done manually. This will require more time. Gao [26] built a health monitoring based on wireless sensor networks to process data from motion capture sensor to get and determine the health level of the tester. This system is said to be developed to measure blood pressure, however it is yet ready for checking the BG level. Another study that employs an innovative technology in the blood monitoring process is Persel and Antsiperov's research [27-28]. Their research monitors a blood pressure, not at the BG level study either [27]. Chen [21] built the monitoring system based on Bluetooth technology to monitor blood oxygen, even though BG level measurement is also needed.

In this study, we propose a non-invasive glucose measurement system developed using a wireless data communication system based on an android application in mobile phone, which is the data of measurement can be stored automatically on android memory. Patients can monitor their BG level themselves regularly. The automatic data stored makes the measurement simpler, less time consuming, low cost, and the data stored in phone memory can be accessed anytime and anywhere.

\section{METHOD}

\section{Hardware and Software Desain}

The design of BG monitoring system is separated into 2 factions, namely the hardware design and the software design. As in Figure 1, the BG data read by the hardware part will be sent to the software via Bluetooth communication. Patients could perform repeated measurements themselves, as the history of measurement data is always stored on the phone. 
Jurnal Penelitian Fisika dan Aplikasinya (JPFA), 2020; 10(2): 103-113

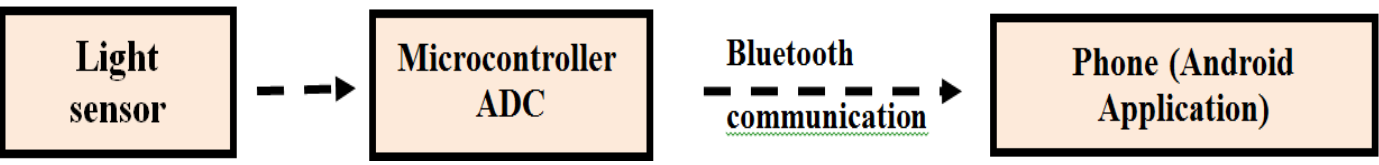

Figure 1. The Block Diagram of the Non-Invasive BG Measurement System

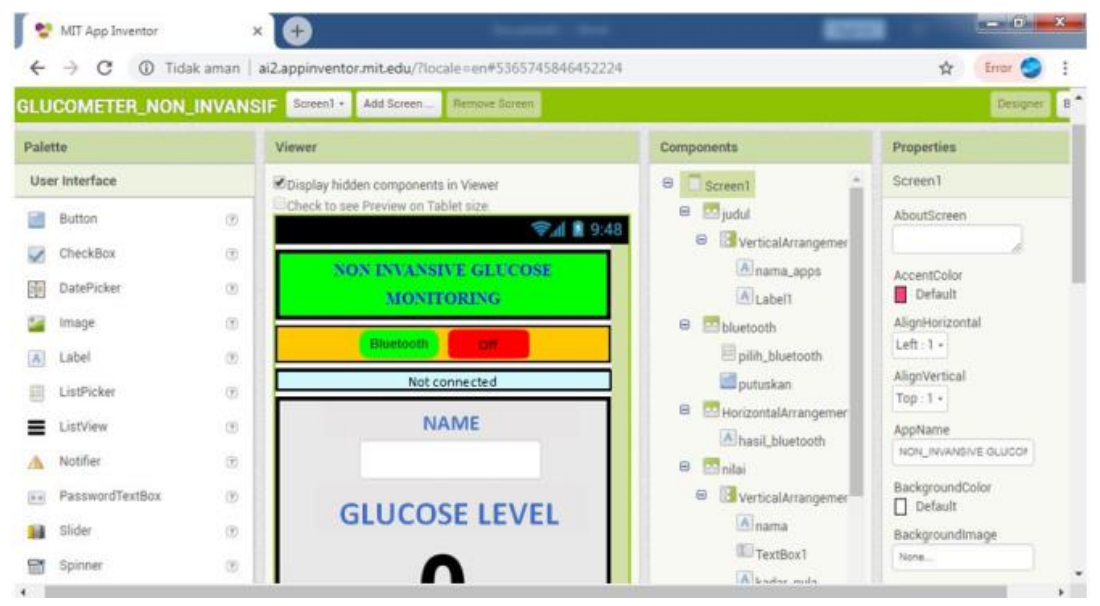

(a)

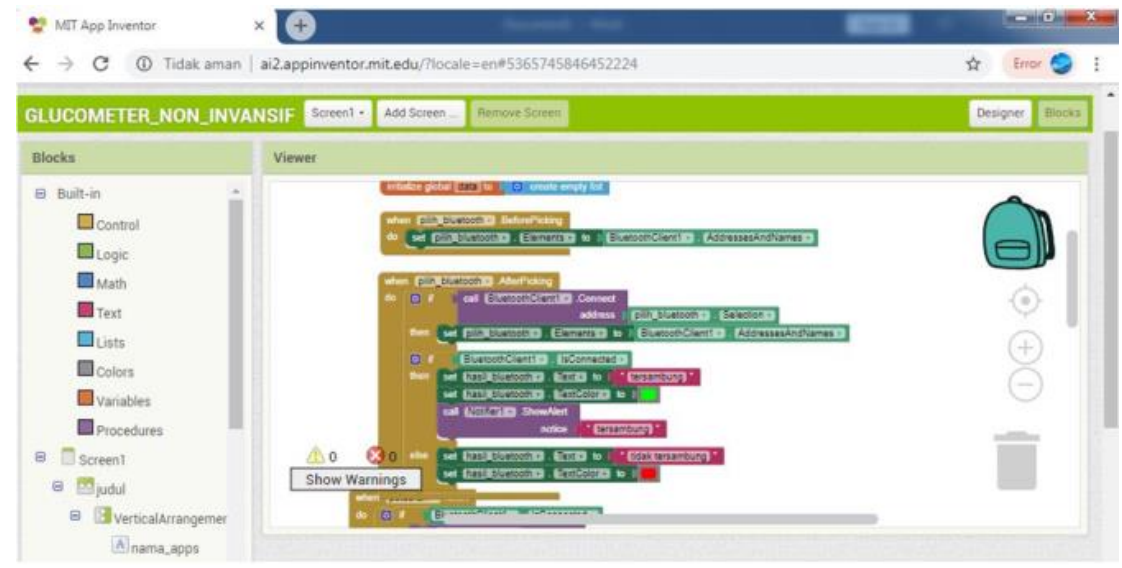

(b)

Figure 2. (a) Part of Designer (b) Part of Block from App Inventor

In the hardware design, there are electronic components that assembled to run the BG measurement and monitoring. The electronic part consisted of a laser source and light sensor, OPT101, that responds to changes in BG level. The OPT101 is analog light sensor with a monolithic photodiode and operated range from 2.7 volt to 36 volt supplies. The photodiode has a very large measurement area that collects a significant amount of light, and thus allows for highsensitivity measurements. The photodiode has a wide spectral response with a maximum peak in the infrared spectrum, and a useable range from $300 \mathrm{~nm}$ to $1,100 \mathrm{~nm}$. The output voltage increases linearly with light intensity. A microcontroller is an electronic device that controls all measurement processes and provides the path for integration of hardware and software [29], and a Bluetooth module for communicating with the phone. A laser as a transmitter emits light passing through skin surface and the blood as object to measure the BG level. Output voltage of the sensor increased linearly with light intensity. The voltage would be processed by the Arduino microcontroller. Arduino had 10 bits ADC which would convert analog voltage from the 
sensor into 0-1,023 bits of ADC. Digital data would be sent to the Android system in phone via Bluetooth communication.

The software part is designed to display measurement data on an application based on Android in phone. The innovative technology of Inventor App developed by MIT is used to find out the application in phone. The visual blocks-based programming language could be accessed through a browser. Project creation with the Inventor App was divided into two stages, namely the designer section to make the application display section on a smart phone as in Figure 2(a) and the block part to program the application that could be run (Figure 2(b)).

Digital data would be displayed in $\mathrm{mg} / \mathrm{dl}$ units on the screen of application Android, and they are saved automatically into smartphone memory in the form of Comma Separated Values (.csv), which could be converted into Microsoft Excel worksheets in Microsoft Office.

\section{Calibration and Test}

After the hardware and software device were built, the calibration process of the sensor was carried out. Blood samples from ten participants were used to convert the voltage (volts) generated by the light sensor to the blood sugar levels (mg/dl). In this calibration process, blood samples were taken in an invasive manner. Each sample were measured in sugar levels with a standard device and with a system designed. The standard tool used to read BG levels is the
GlucoDr merk from Allmedicus. Measurements with the developed system were carried out repeatedly (five times) for each samples. The five data were then averaged. The equation from the graph of the calibration of the electric voltage to the BG level would be used as the basic equation in the microcontroller program for further measurements.

The next step is a testing the Bluetooth communication connection system. This step is applied to ensure the data which were sent by the hardware has the same value as the data received and displayed on the Android application. The numbers that appeared on the Arduino would be compared with the value of serial monitoring on a computer and a phone (Android) application. If the two displays are the same, it means that the data communication via Bluetooth has been going well. Lastly, the whole measurement system using a non-invasive was tested, and the result will be compared with of those the invasive measurements. For the first data, a BG level will be measured non-invasively with a designed instrument. Then with the same person, BG is measured invasively. Measurement is done alternately and continuously for further data, without storing invasive samples in the refrigerator or the like. This is because the delay of measurement between invasive sampling and measuring process can affect value of $B G$ level. In summary, all stages of the study can be outlined in Figure 3.

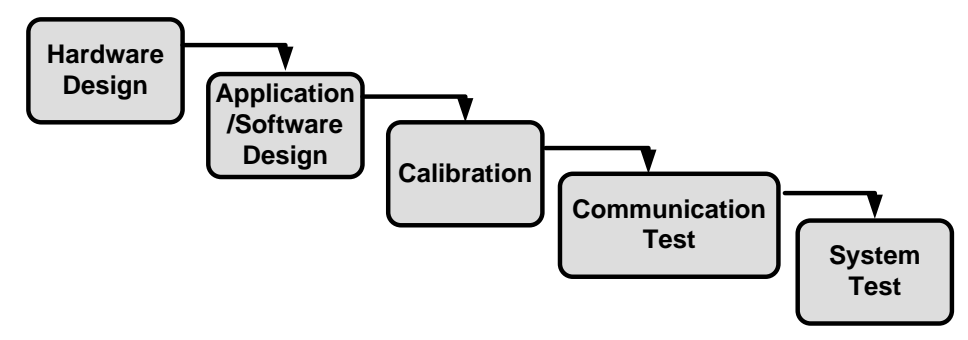

Figure 3. Stages of Research 


\section{III.RESULTS AND DISCUSSION}

Figure 4 is a non-invasive $\mathrm{BG}$ level monitoring instrument with an android application designed to display measurement data. The sensor part is placed on a clampshaped device. This form is made with the aim that the distance between the laser and the light sensor with the surface of the skin to be irradiated has a close and constant distance. As Chen's [1] research, the surface pressure of the skin touching the sensor can affect the measurement data, so a right and constant sensor position is needed. A certain distance between the light and skin surface should be maintain to control it travels [21].

In addition, the light background variation from the body and environment will also affect the sensitivity of the light sensor [18]. The brace is placed on the tip of the patient's little finger while the measuring is about to start. Then, the hardware and application are connected with Bluetooth communication, so that data can appear on the Android. The use of Bluetooth has an increasing trend everywhere, because its framework facilitates to develop more devices [21]. The electronic box is the electrical data processing unit. The result of measurement will be displayed on the phone.

A clamp shape device (detector part)

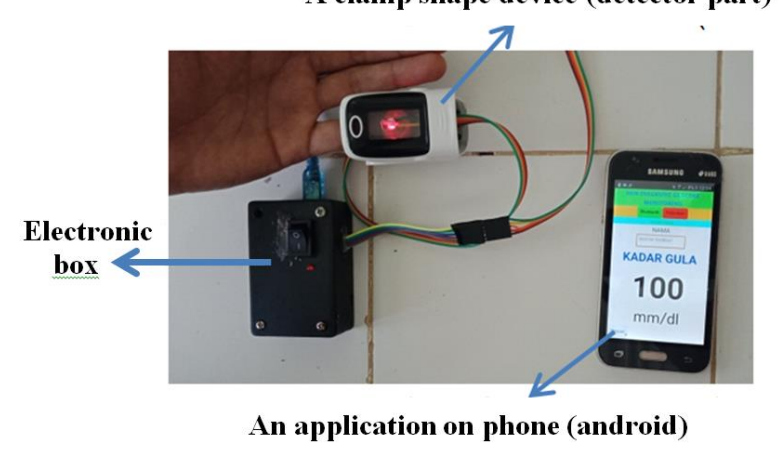

Figure 4. The Non-Invasive BG Level

Measurement Instrument

In the data communication system via Bluetooth, the testing is done by using the serial monitoring on Arduino Ide facilities. The design system measures any data; the data that appears in the monitoring series is used as a reference to see the data that appears on the android application. In Figure 5, the voltage data that appears in serial monitoring has an exactly the same value as the data read in the application, and the two values can be displayed simultaneously with no delayed in between (real time). The real time measurement system will prevent a complication in health [29]. This occurrence shows that communication between the two devices can work properly.

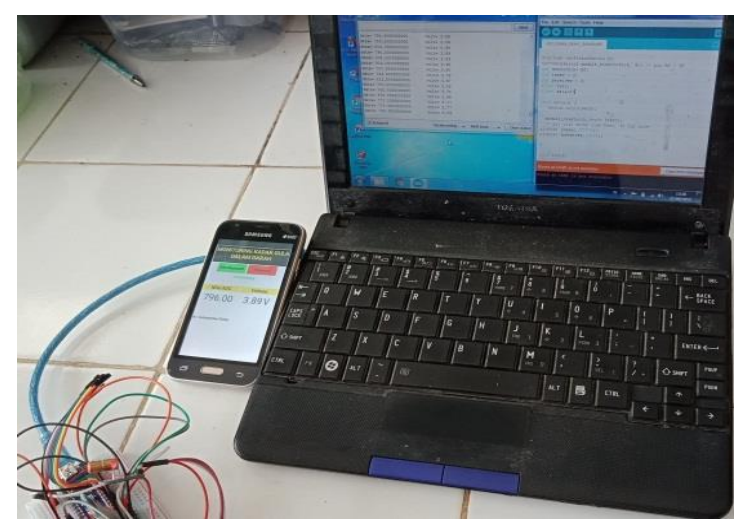

Figure 5. Serial Monitoring on Arduino Ide's Facilities

The sensor calibration is done by taking blood samples from ten of participants in an invasive manner. Each BG level of the sample will be measured with both standard tools and developed system. The standard tool read a BG level in an $\mathrm{mg} / \mathrm{dl}$ unit, while the developed system will deliver a BG level in units of voltage (volts). The calibration results can be seen in Figure 6. The tested blood samples have values ranging from 94 to 120 $\mathrm{mg} / \mathrm{dl}$. At that range, the voltage generated by the sensor is in the range of 4.13-4.27 volts. The analog output voltage from the sensor will be digitized by the analog digital converter (ADC) on the Arduino. Digital numbers will be converted into $\mathrm{mg} / \mathrm{dl}$ units based on the results of the calibration with standard equipment. From the calculation of the calibration, the data will be sent and displayed on the app. Based on these results, the BG level changing measured by standard equipment produces a slightly different 
voltage response when read by a developed system. This condition can occur due to the effect of environmental light and temperature during the samples calibration process [18,30], so that the calibration requires constant light and temperature control [31]. In addition, the difference in the volume of blood samples during the calibration process can cause the responsiveness of the developed system. The first sample volume is not exactly the same as the next samples, hence it affects the light intensity that is received by the light sensor. As in Min's research, when there is no blood without glucose, the volume is very influential [18].

The calibration results in equation of graph are used in the embedded program in the microcontroller. The equation is a correction to reduce errors in the calibration process. The correction is an important way to get good measurement results. Other researchers have other ways to correct the measurement data, such as by adding a relative reference measurement [18]. With this program, the voltage unit can be converted directly to a BG level in $\mathrm{mg} / \mathrm{dl}$ unit. So that, the measurement results that sent to the android/phone can already be displayed in units of BG levels $(\mathrm{mg} / \mathrm{dl})$.

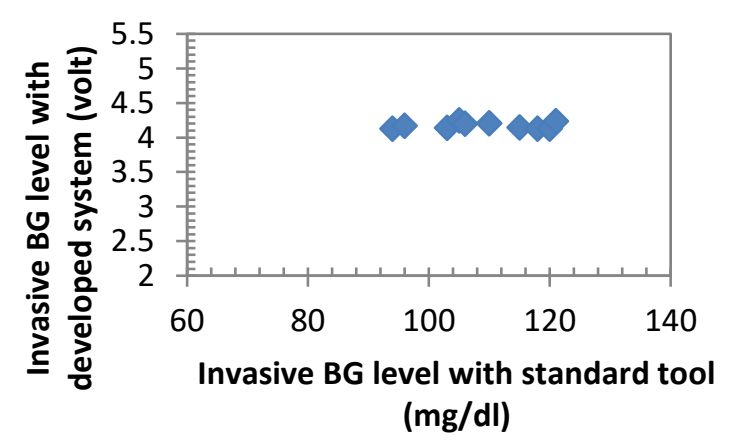

Figure 6. Calibration Result of the Light Sensor

Next, the results of the tested of noninvasive BG level monitoring system can be seen in Figure 7. The test of the developed system is carried out on several people with different BG levels. The results of noninvasive measurements are compared with of those invasive method. A person will be measured in a non-invasive method, and then his blood will be taken with an invasive method using standard tools. Actually, a person's psychological and activity will affect blood glucose levels [30,32]. Invasive and non-invasive measurements are performed in parallel. Non-invasive measurement data appears and automatically save on the Android application.

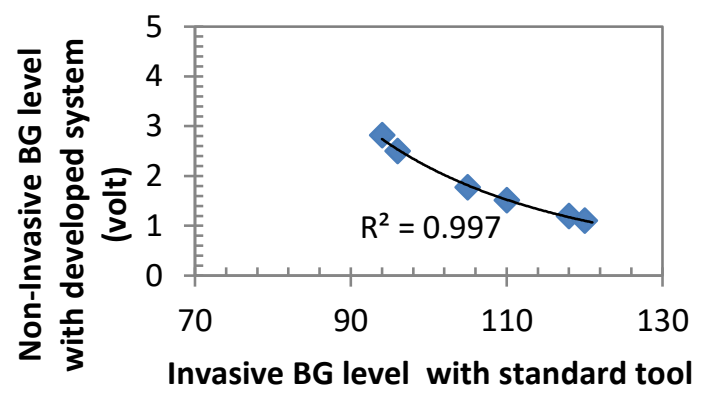

Figure 7. The Results of Tested of Non-Invasive BG Level Monitoring System

Figure 7 shows the inverse relationship between the BG level and the voltage generated by the developed tools. By increasing the BG level, the output voltage becomes lower. For $94 \mathrm{mg} / \mathrm{dl}$ of BG level, it is found to be 2.86 volts at the output voltage. While the BG level is getting higher $(120 \mathrm{mg} / \mathrm{dl})$, the voltage output measured by the developing system is 1.2 volts. Based on the power of regression type, the $r$-squared is 0.997, which means a closed relation between BG level and the voltage and a small error rate. The increase of BG level affects the value of the resistance between the transmitter, and the receiver of sensors will be decreased. A laser as a transmitter emits light passing blood, which is blood that has various density so that the intensity landed to the sensor will change too [2]. Furthermore, the textures and characteristics of the skin, some researcher called with skin permittivity, will involve the light intensity that is received by the sensor $[18,20,21]$. There are four responses of the skin/ tissue to light i.e. reflected, diffused, 
absorbed, and transmitted as shown in Figure 8. Thus, the voltage drop generated by the sensor can cause any of the four responses as given in Figure 8.

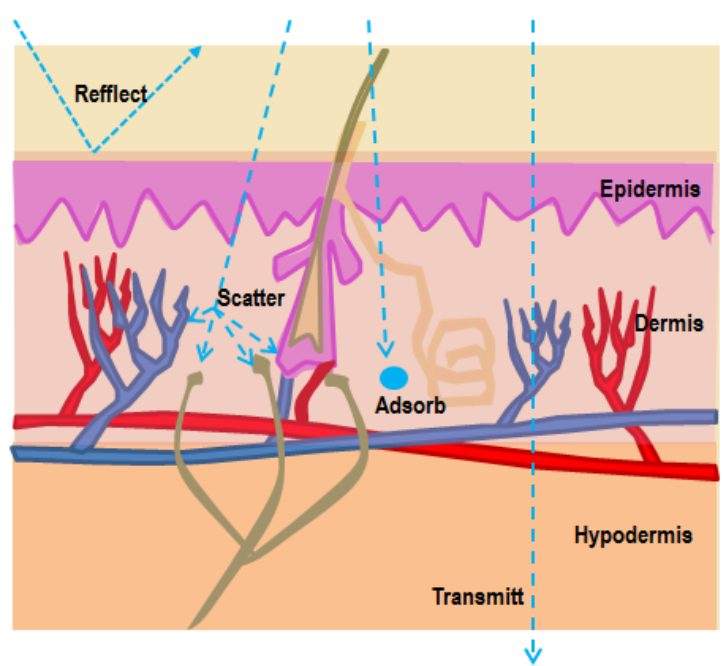

Figure 8. The Outcomes of Skin Response Arrived Light

The voltage change that read by the developed system appears to be more responsive to variations in $\mathrm{BG}$ levels by measuring a non-invasive sample (Figure 7) when compared to measurements of an invasive sample (Figure 6). The occasion due to the influence of each of invasive samples volume that was tested has not been exactly the same. In addition, the transmitter emits light to drop blood samples, which is easy to be affected by light in the area. The light on the skin layer can interference which affects the intensity measured by the sensor [33,34].

Overall the non-invasive BG level monitoring system can read well the changes in glucose with a voltage response. Nevertheless, there are some limitations to test the system in large BG level. The range of measurement of the system should be developed. The ideal condition of measurement need to be presented to decrease data correction. Therefore, testing noninvasive glucose with a developed monitoring system will be more accurately carried out on parts of the body with a smooth epidermal surface texture such as auricle.
The developed of non-invasive glucose monitoring system based on phone has the potential to provide convenience in measuring and monitoring BG levels for patients. The electronic systems and technology used in medical field will provide other opportunities for application in other fields or tools.

\section{CONCLUSION}

The study discusses a non-invasive BG measurement system where the measurement data can be monitored and stored directly to the patient's phone. The measurement results will be displayed on Android using Bluetooth communication. The specific of the system is data storage and the monitoring of patient conditions are contained in the respective phone applications. The monitoring of the patients can be done easily at any time. From the results of the system testing, it is found that the increase in glucose levels in the blood caused a decrease in the voltage generated by the sensor. This system is able to read well the changes in BG levels with a voltage response, although it is still influenced by several aspects, namely light and ambient temperature, skin surface, blood viscosity and health status of the participants.

\section{ACKNOWLEDGMENT}

This research has been funded by "Penerima Negara Bukan Pajak (PNBP)" fund of Faculty of Medicine and Health Sciences, Bengkulu University with number cooperative contract 1355/UN30.14/KS/2018.

\section{REFERENCES}

[1] Chen JY, Zhou Q, Xu G, Wang TR, Tai EG, Xie L, Zhang Q, Guan Y and Huang X. NonInvasive Blood Glucose Measurement of $95 \%$ Certainty by Pressure Regulated Mid-IR. Talanta. 2019; 197: 211-217. DOI: https://doi.org/10.1016/j.talanta.2019.01.034

[2] Ouyang C, Zhoub P, and Gan Z. A NonInvasive Test Method for Type-2 Waveform 
Jurnal Penelitian Fisika dan Aplikasinya (JPFA), 2020; 10(2): 103-113

Diabetes Mellitus by Pulse Fitting. Biomedical Signal Processing and Control. 2020; 60: 102000. DOI:

https://doi.org/10.1016/j.bspc.2020.102000.

[3] Zheng H, He J, Li P, Guo M, Jin H, Shen J, Xie Z, and Chi C. Glucose Screening Measurements and Noninvasive Glucose Monitor Methods. Procedia Computer Science. 2018; 139: 613-62. DOI:

https://doi.org/10.1016/j.procs.2018.10.202.

[4] Xue J, Liming Y, Chunyan L, Mingxiang Z, and Peng L. Rapid and Nondestructive Measurement of Glucose in A Skin Tissue Phantom by Near-Infrared Spectroscopy. Optik. 2018; 170: 30-36. DOI: https://doi.org/10.1016/j.ijleo.2018.05.050.

[5] Rodin D, Kirby M, Sedogin N, Shapiro Y, Pinhasov A, and Kreinin A. Comparative Accuracy of Optical Sensor-Based Wearable System for Noninvasive Measurement of Blood Glucose Concentration. Clinical Biochemistry. 2019; 65: 15-20. DOI:

https://doi.org/10.1016/j.clinbiochem.2018.1 2.014.

[6] Juan CG, Bronchalo E, Torregrosa G, Avila E, Garcia N, and Navarro JMS. Dielectric Characterization Of Water Glucose Solutions Using A Transmission/Reflection Line Method. Biomedical Signal Processing and Control. 2017; 31: 139-147. DOI:

http://dx.doi.org/10.1016/j.bspc.2016.07.011

[7] Karyakin AA, Nikulina SV, Vokhmyanina DV, Karyakina EE, Anaev EKH, and Chuchalin AG. Non-Invasive Monitoring of Diabetes Through Analysis of The Exhaled Breath Condensate (Aerosol). Electrochemistry Communications. 2017; 83: 81-84. DOI:

http://dx.doi.org/10.1016/j.elecom.2017.09.0 05 .

[8] Kim S, Melikyan H, Kim J, Babajanyan A, Enkhtur L, Friedman B, Lee K, and Lee JH. Noninvasive In Vitro Measurement Of PigBlood D-Glucose by Using A Microwave Cavity Sensor. Diabetes Research and
Clinical Practice. 2012; 96(3): 379-384. DOI:

https://doi.org/10.1016/j.diabres.2012.01.01 $\underline{8}$.

[9] Kubota T, Kubota $\mathrm{N}$ and Kadowaki $\mathrm{T}$. Imbalanced Insulin Actions in Obesity and Type 2 Diabetes: Key Mouse Models of Insulin Signaling Pathway. Cell Metabolism. 2017; 25(4): 797-810. DOI:

http://dx.doi.org/10.1016/j.cmet.2017.03.004

[10] Sharma S, Takagi E, Cass T, Tsugawa W, and Sode K. Minimally Invasive Microneedle Array Electrodes Employing Direct Electron Transfer Type Glucose Dehydrogenase for The Development of Continuous Glucose Monitoring Sensors. Procedia Technology. 2017; 27: 208-209. DOI:

https://doi.org/10.1016/j.protcy.2017.04.087.

[11] Li J, Koinkar P, Fuchiwaki Y, and Yasuzawa M. A Fine Pointed Glucose Oxidase Immobilized Electrode for Low-Invasive Amperometric Glucose Monitoring. Biosensors and Bioelectronic. 2016; 86: 9094. DOI:

http://dx.doi.org/10.1016/j.bios.2016.06.037.

[12] Arakawa T, Kuroki Y, Nitta H, Chouhan P, Toma K, Sawada SI, Takeuchi S, Sekita T, Akiyoshi K, Minakuchi S, and Mitsubayashi K. Mouthguard Biosensor with Telemetry System for Monitoring of Saliva Glucose: A Novel Cavitas Sensor. Biosensors and Bioelectronics. 2015; 84: 106-111. DOI: http://dx.doi.org/10.1016/j.bios.2015.12.014.

[13] Liang Y, Wanderer J, Nichols JH, Klonoff D, and Rice MJ. Blood Gas Analyzer Accuracy of Glucose Measurements. Mayo Clinic Proceedings. July 2017; 92(7): 1030-1041. DOI:

http://dx.doi.org/10.1016/j.mayocp.2017.03. 009.

[14] Budiyanto M, Yasin M and Harun SW. Sensitivity Approach of Optical Sensors of Cholesterol Detection through Gaussian Beamand Quasi-Gaussian Beam. Jurnal Penelitian Fisika dan Aplikasinya (JPFA). 
Jurnal Penelitian Fisika dan Aplikasinya (JPFA), 2020; 10(2): 103-113

2019; 9(1): 22-31. DOI:

http://dx.doi.org/10.26740/jpfa.v9n1.p22-31.

[15] Kumar N, Salehilashkajani A, Zhang HD, Ady M, Forck P, Glutting J, Jones OR, Kersevan R, Doddington TM, Mazzoni S, Rossi A, Schneider G, Udrea S, Veness R, and Welsch CP. Non-Invasive Beam Profile Monitor for Medical Accelerators. Physica Medica. 2020; 74: 173-178. DOI: https://doi.org/10.1016/j.ejmp.2020.04.023.

[16] Pandey I and Tiwari JD. A Novel Dual Imprinted Conducting Nanocubes Based flexible Sensor for Simultaneous Detection of Hemoglobin and Glycated Haemoglobin in Gestational Diabetes Mellitus Patients. Sensors and Actuators B: Chemical. 2019; 285: 470-478. DOI: https://doi.org/10.1016/j.snb.2019.01.093.

[17] Jeong B, Jung CH, Lee YH, Shin IH, Kim H, Bae SJ, Lee DS, Kang ES, Kang U, Kim JJ, and Park JY. A Novel Imaging Platform for Non-Invasive Screening of Abnormal Glucose Tolerance. Diabetes Research and Clinical Practice. 2016; 116: 83-85.

http://dx.doi.org/10.1016/j.diabres.2016.03.0 14.

[18] Min X, Liu R, Fu B, and Xu K. A Preliminary Verification of The floating Reference Measurement Method for NonInvasive Blood Glucose Sensing. Optics \& Laser Technology. 2017; 91: 7-12. DOI: http://dx.doi.org/10.1016/j.optlastec.2016.12 .011 .

[19] Soni A, and Jha SK. Smartphone Based NonInvasive Salivary Glucose Biosensor. Analytica Chimica Acta. 2017; 996: 54-63. DOI:

https://doi.org/10.1016/j.aca.2017.10.003.

[20] Huang J, Zhang Y, and Wu J. Review of NonInvasive Continuous Glucose Monitoring Based on Impedance Spectroscopy. Sensors and Actuators A. 2020; 311: 112103. DOI: https://doi.org/10.1016/j.sna.2020.112103.

[21] Chen Q and Tang L. A Wearable Blood Oxygen Saturation Monitoring System Based on Bluetooth Low Energy Technology. Computer Communications. 2020; 160 :101110. DOI:

https://doi.org/10.1016/j.comcom.2020.05.0 $\underline{41}$.

[22] Falco ID, Cioppa AD, Giugliano A, Marcelli A, Koutny T, Krcma M, Scafuri U, and Terantino E. A Genetic Programming-Based Regression for Extrapolating A Blood Glucose-Dynamics Model from Interstitial Glucose Measurements and Their First Derivatives. Applied Soft Computing Journal. 2019; 77: 316-328. DOI:

https://doi.org/10.1016/j.asoc.2019.01.020.

[23] Wang Y, Hu X, Tang J, Wang W, Dong L, Zhou J, and Jia W. Traceability to A Primary Reference Measurement Procedure (IDLCMS); A key Step in Validating The Clinical Accuracy and Safety of Hospital Blood Glucose Monitoring Systems. Clinica Chimica Acta. 2018; 486: 275-281. DOI: https://doi.org/10.1016/j.cca.2018.08.025.

[24] Varady NH, Schwab PE, Jones T, Collins JE, Fitz W, and Chen AF. Optimal Timing of Glucose Measurements after Total Joint. Arthroplasty. The Journal of Arthroplasty. 2019; 34(7): S152-S158. DOI:

https://doi.org/10.1016/j.arth.2019.01.004.

[25] Ray PP, Dash D, and Kumar N. Sensors for internet of medical things: State-of-The-Art, Security and Privacy Issues, Challenges and Future Directions. Computer Communications. 2020; 160: 111-131. DOI: https://doi.org/10.1016/j.comcom.2020.05.0 29.

[26] Gao L, Zhang G, Yu B, Qiao Z, and Wang J. Wearable Human Motion Posture Capture and Medical Health Monitoring Based on Wireless Sensor Networks. Measurement. 2020; 166: 108252. DOI:

https://doi.org/10.1016/j.measurement.2020. 108252.

[27] Persell SD, Karmali KN, Stein N, Jim Li J, Peprah YA, Lipiszko D, Ciolino JD, and Sato H. Design of A Randomized Controlled 
Jurnal Penelitian Fisika dan Aplikasinya (JPFA), 2020; 10(2): 103-113

Trial Comparing A Mobile Phone-Based Hypertension Health Coaching Application to Home Blood Pressure Monitoring Alone: The Smart Hypertension Control Study. Contemporary Clinical Trials. 2018; 73: 92-97. DOI:

https://doi.org/10.1016/j.cct.2018.08.013.

[28] Antsiperov V, Mansurov G, and Danilychev M. Non-Invasive Arterial Pressure Monitoring By A New Pneumatic Sensor and On-Line Analysis of Pulse Waveforms for A Modern Medical Home Care Systems. Procedia Computer Science. 2020; 176: 2894-2903. DOI:

https://doi.org/10.1016/j.procs.2020.09.264.

[29] Vezouviou E, Lowe CR. A Near Infrared Holographic Glucose Sensor. Biosensors and Bioelectronics. 2015; 68: 371-381. DOI: http://dx.doi.org/10.1016/j.bios.2015.01.014

[30] Dumke CL, Slivka DR, Cuddy JS, Hailes WS, Rose SM, and Ruby BC. The Effect of Environmental Temperature on Glucose and Insulin After an Oral Glucose Tolerance Test in HealthyYoung Men. Wilderness \& Environmental Medicine. 2015; 26(3): 335342. DOI:

https://doi.org/10.1016/j.wem.2015.03.002.
[31] Hao Y, Chen YW, He XL, Yang F, Han RX, Yang CL, Li W, and Qian ZY. Near-infrared Responsive 5-Fluorouracil and Indocyanine Green Loaded MPEG-PCL Nanoparticle Integrated With Dissolvable Microneedle for Skin Cancer Therapy. Bioactive Materials. 2020; 5(3): 542-552. DOI:

https://doi.org/10.1016/j.bioactmat.2020.04. $\underline{002}$.

[32] Havenith G and Lloyd AB. Counterpoint to "Infrared Cameras Overestimate Skin Temperature During Rewarming from Cold Exposure". Journal of Thermal Biology. 2020; 92: 102663. DOI:

https://doi.org/10.1016/j.jtherbio.2020.10266 3.

[33] Hsiu H, Hu HF, and Tsai HC. Differences in Laser-Doppler Indices Between Skin-Surface Measurement Sites in Subjects with Diabetes. Microvascular Research. 2018; 115: 1-7. DOI:

http://dx.doi.org/10.1016/j.mvr.2017.07.004.

[34] Khan F and Pickup JC. Near-infrared Fluorescence Glucose Sensing Based on Glucose/Galactose-Binding Protein Coupled to 651-Blue Oxazine. Biochemical and Biophysical Research Communications. 2013; 438(3): 488-492. DOI:

http://dx.doi.org/10.1016/j.bbrc.2013.07.111. 